\title{
Childhood Gastric Carcinoma
}

National Cancer Institute

\section{Source}

National Cancer Institute. Childhood Gastric Carcinoma. NCI Thesaurus. Code C118813.

A rare carcinoma of the stomach that occurs during childhood. 